\title{
Announcing. . .
}

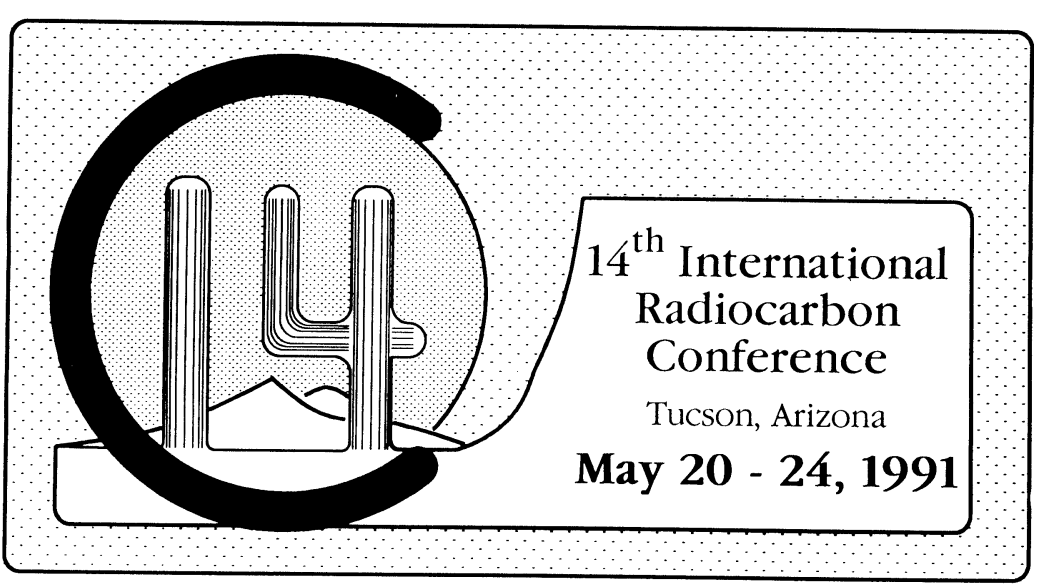

An international meeting on research in Radiocarbon Dating, Accelerator Mass Spectrometry and Related Fields.

First circular will be sent September 1989.

Contact: Dr. Austin Long

Department of Geosciences

University of Arizona

Tucson, AZ 85721 USA

FAX: 602-621-2672

Telex: $650-3839821$

BITNET: C14@ARIZRVAX 


\section{AMS GEOSCIENTIST}

Purdue University is upgrading its Tandem Accelerator to establish a research center for Accelerator Mass Spectrometry (AMS). This instrument will mainly analyze ${ }^{36} \mathrm{Cl},{ }^{129} \mathrm{I},{ }^{41} \mathrm{Ca},{ }^{10} \mathrm{Be},{ }^{26} \mathrm{~A} 1$, and ${ }^{14} \mathrm{C}$ to solve scientific problems in Solid Earth and Atmospheric Sciences. Professor David Elmore has joined the Physics Department to help establish this facility and substantial start-up funds have been provided.

Purdue's Department of Earth and Atmospheric Sciences seeks a well-established geoscientist whose research involves isotopes that can be analyzed by AMS. We especially seek applicants with AMS-related experience in hydrology, surficial processes, climatology, physical geography or biogeochemical cycles who have demonstrated an ability to obtain external funding.

The successful applicant will teach courses in his/her specialty, have essentially unlimited access to the facility, and assume a major role in directing overall research-and-development priorities. Rank and salary for this faculty position will depend on qualifications.

Send vita, statement of AMS-related research and experience, and names of three references to: Dr. Steven J. Fritz, Department of Earth and Atmospheric Sciences, Purdue University, West Lafayette, IN 47907. Screening will commence on May 1 and will continue until the position is filled. Purdue University is an affirmative action/equal opportunity employer. 


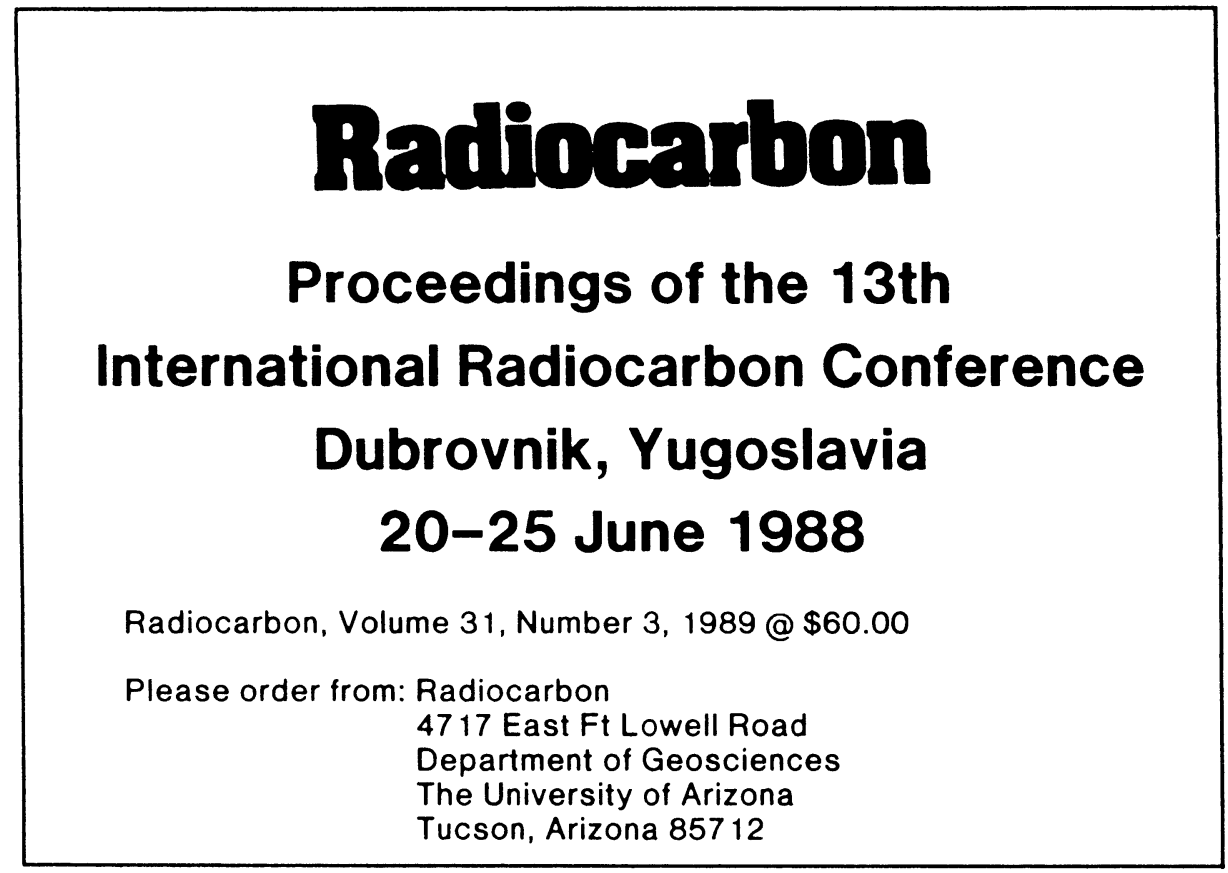




\section{4 \\ C \\ Announcing. . .}

\section{$R A D I O C A R B O N$ has moved to}

\section{The University of Arizona}

and has become

An International Journal of Cosmogenic Isotope Research

Our new address is:

\section{RADIOCARBON}

4717 East Ft Lowell Road

Department of Geosciences

University of Arizona

Tucson, AZ 85712

(602)881-0857

BITNET:C14@ARIZRVAX

\section{Editor: Austin Long}

Managing Editor: Renee Kra

We are expanding our outlook to include special volumes, conference proceedings and chronometric studies in cross-disciplinary fields such as AMS, Archaeology, Climatology, Global Change, International Radiocarbon Data Base (IRDB) and Paleoecology. Book reviews, discussions, advertising exchanges and conference notices will also be featured.

Please send all correspondence, remittances and manuscripts to the above address.

Current subscription rates are:

Vol 31, Nos. 1-3, 1989 (includes Proceedings of the

13th International Radiocarbon Conference) ....\$ $90.00 /$ Institution $60.00 /$ Individual

Special Package Offer:

Full set, Vols 1-30 (1959-1988)

500.00

(Plus postage and handling) 


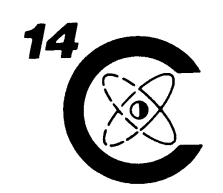

RADIOCARBON

An International Journal

of Cosmogenic Isotope

Research
4717 East Ft Lowell Road

Department of Geosciences

The University of Arizona

Tucson, AZ 85712

Tel: (602)881-0857

BITNET:C14@ARIZRVAX

PRICE LIST

Proceedings of the 13th International Radiocarbon Conference (Vol 31, No. 3, 1989)

Proceedings of the 12th International Radiocarbon Conference (Vol 28, Nos. 2A \& 2B, 1986-available separately at $\$ 30.00$ ea)

Proceedings of the 11 th International Radiocarbon Conference (Vol 25, No. 2, 1983)

Proceedings of the 10th International Conference (Vol 22, Nos. $2 \& 3,1980$ )

Vol 31, Nos. 1-3, 1989 (includes Proceedings)

Vol 30, Nos. 1-3, 1988

Vol 29, Nos. 1-3, 1987

Vol 28, Nos. 1, 2A \& 2B, 3, 1986 (includes Proceedings)

Vol 27, Nos. 1, 2A \& 2B, 3, 1985

Vol 26, Nos. 1-3, 1984

Vol 25, Nos. 1-3, 1983 (includes Procecdings)

Vol 24, Nos. 1-3, 1982

Vol 23, Nos. 1-3, 1981

Vol 22, Nos. 1-4, 1980 (includes Procecdings)

Vols 11-21, 1969-1979

Vols 1-9, 1959-1967

Comprehensive Index (1950-1965)

$\$ 60.00$

$\$ 60.00$

$\$ 50.00$

$\$ 60 .(0)$

$\$ 90.00 / \mathrm{vol}$ Inst $\$ 60.00 / \mathrm{vol}$ Ind $\$ 85.00 / \mathrm{vol}$ Inst $\$ 55.00 / \mathrm{vol}$ Ind $\$ 75.00 / \mathrm{vol}$ Inst $\$ 50.00 / \mathrm{vol}$ Ind

$\$ 80.00 / \mathrm{vol}$ Inst $\$ 60.00 / \mathrm{vol}$ Ind $\$ 75.00 / \mathrm{vol}$ Inst $\$ 50.00 / \mathrm{vol}$ Ind $\$ 75.00 / \mathrm{vol}$ Inst $\$ 50.00 / \mathrm{vol}$ Ind

$\$ 75.00 / \mathrm{vol}$ Inst $\$ 50.00 / \mathrm{vol}$ lnd $\$ 60.00 / \mathrm{vol}$ Inst $\$ 40.00 / \mathrm{vol}$ Ind $\$ 60.00 / \mathrm{vol}$ Inst $\$ 40.00 / \mathrm{vol}$ Ind

$\$ 80.00 / \mathrm{vol}$ Inst $\$ 60.00 / \mathrm{vol}$ Ind $\$ 60.00 / \mathrm{vol}$ Inst $\$ 40.00 / \mathrm{vol}$ Ind $\$ 20.00 / \mathrm{vol}$

$\$ 20.00$ Single issue

$\$ 20.00$

Out of Print:

Vol 10, Nos. 1 \& 2, 1968

Vol 11, No. 2, 1969

Vol 12, No. 2, 1970

Vol 13, No. 1, 1971

Vol 14, No. 1, 1972

$\begin{array}{ll}\text { Special Package (ffer: } & \\ \text { Full set, Vols 1-30) } & \$ 500.00) \\ \quad(1959-1988) & \\ \text { Postage \& handling } & \\ \text { USA } & \\ \text { Foreign } & \\ \end{array}$

Forcign postage \& sales tax on current volumes $\$ 10.00 / \mathrm{vol}$

Current domestic subscriptions will be charged sales tax

Postage \& handling will be added to back orders 


\section{Archaeometry}

The research journal for those interested in the involvement of the physical sciences in archaeology and art history. Articles are written with the non-specialist in mind, providing a window onto this stimulating field of application, and giving up-todate guidance on topics in a rapidly developing area of research.

Contents of Volume 31, part 2

The Oxford accelerator mass spectrometry facility: technical developments in routine dating....R.E.M. Hedges, I.A. Law, C.R. Bronk \& R.A. Housley.

Iznik pottery: an investigation of the methods of production....M.S. Tite.

Science versus art history: the Cleveland Museum head of Pan and the Mittiades Marathon victory monument....N. Hertz, A.P. Grimanis, H.S. Robinson, D.B. Wenner \& M. VassilakiGrimani.

The abuse of bone analyses for archaeological dietary studies....

R.G.V. Hancock, M.D. Grynpas \& K.P.H. Pritzker.

The technology of sixteenth- and seventeenth-century Chinese cloisonné enamels...J. Henderson, M. Tregear \& N. Wood.

Archaeometallurgical fieldwork and the use of a portable X-ray spectrometer...D. Helmig, E. Jackwerth \& A. Hauptmann.

Obsidian dating: recent advances in the experimental determination and application of hydration rates....C.M. Stevenson, J. Carpenter \& B.E. Scheetz.

Luminescence Dating: a guide for non-specialists....M.J. Aitken.

Radiocarbon dates from the Oxford AMS system: Archaeometry datelist 9...R.E.M. Hedges, R.A. Housley, I.A. Law \& C.R. Bronk.

The current subscription price of a volume is £20 sterling (Europe) and US\$ 50 elsewhere. For individuals there is a reduced price of $£ 14$ sterling (Europe) and US\$35 elsewhere. For details please write to the Archaeometry Manager, 6 Keble Road, oxford OX1 3QJ, UK. 


\title{
INTERNATIONAL WORKSHOP ON INTERCOMPARISON OF RADIOCARBON LABORATORIES
}

\author{
GLASGOW, 12-15 SEPTEMBER 1989
}

A workshop was held in Glasgow in September, 1989 on the topic of the InterComparison of Radiocarbon Laboratories. The meeting was hosted by the University of Glasgow, Scottish Universities Research and Reactor Centre and the NERC ${ }^{14} \mathrm{C}$ laboratory at East Kilbride. The scientific programme of the workshop covered previous and current intercomparison studies of radiocarbon laboratories, as well as future developments in this field.

The Proceedings will be published by $R A D I O$ $C A R B O N$ as a Special Issue in Volume 32, No. 3, 1990. Participants should submit three doublespaced copies (with diskette, if available) of their manuscripts by November 15, 1989. Manuscripts received after this date will not be included in the Proceedings. Manuscripts should not exceed 10 printed pages.

Participants should submit manuscripts to:
RADIOCARBON
4717 East Ft Lowell Road
Department of Geosciences
The University of Arizona
Tucson, AZ 85712
Tel: (602) 881-0857
Fax: (602) 621-2672
E-mail: C14@ARIZRVAX 


\section{REVISED NOTICE TO READERS AND CONTRIBUTORS}

Since its inception, the basic purpose of RADIOCARBON has been the publication of compilations of ${ }^{14} \mathrm{C}$ dates produced by various laboratories. These lists are extremely useful for the dissemination of basic ${ }^{14} \mathrm{C}$ information.

In recent years, RADIOCARBON has also been publishing technical and interpretative articles on all aspects of ${ }^{14} \mathrm{C}$. We would like to encourage this type of publication on a regular basis. In addition, we will be publishing compilations of published and unpublished dates along with interpretative text for these dates on a regional basis. Authors who would like to compose such an article for his/her area of interest should contact the Managing Editor for information.

Other sections recently added to our regular issues include NOTES AND COMMENTS, LETTERS TO THE EDITOR and ANNOUNCEMENTS. Authors are invited to extend discussions or raise pertinent questions to the results of scientific investigations that have appeared on our pages. These sections include short, technical notes to relay information concerning innovatives sample preparation procedures. Laboratories may also seek assistance in technical aspects of radiocarbon dating. Book reviews are also encouraged as are advertisements.

Manuscripts. Papers may now be submitted on both floppy diskettes and hard copy. When submitting a manuscript on a diskette, always include two hard copies, double-spaced, or wait until the final copy is prepared, after review, before sending the edited diskette. We will accept, in order of preference, WordPerfect, 5.0 or 4.2, Microsoft Word, WordStar or any major Macintosh or IBM word-processing software program. ASCII files, MS DOS and CPM formatted diskettes are also acceptable. The diskettes should be either $31 / 2$ " (720K or 1.44 megabytés) or $51 / 4^{\prime \prime}$ (360K or 1.2 megabytes). Radiocarbon papers should follow the recommendations in RADIOCARBON Style Guide (R, 1984, v 26, p 152-158). Our deadline schedule for submitting manuscripts is:

$$
\text { For Date }
$$

Vol 32, No. 1, 1990

Vol 32, No. 2, 1990

Sept 1,1989

Jan 1, 1990

Half life of ${ }^{14} \mathrm{C}$. In accordance with the decision of the Fifth Radiocarbon Dating Conference, Cambridge, 1962, all dates published in this volume (as in previous volumes) are based on the Libby value, $5568 \mathrm{yr}$, for the half-life. This decision was reaffirmed at the 11 th International Radiocarbon Conference in Seattle, Washington, 1982. Because of various uncertainties, when ${ }^{14} \mathrm{C}$ measurements are expressed as dates in years BP the accuracy of the dates is limited, and refinements that take some but not all uncertainties into account may be misleading. The mean of three recent determinations of the half life, $5730 \pm 40 \mathrm{yr}$, (Nature, v 195 , no. 4845, p 984, 1962), is regarded as the best value presently available. Published dates in years BP can be converted to this basis by multiplying them by 1.03 .

$A D / B C$ Dates. In accordance with the decision of the Ninth International Radiocarbon Conference, Los Angeles and San Diego, 1976, the designation of AD/BC, obtained by subtracting AD 1950 from conventional BP determinations is discontinued in Radiocarbon. Authors or submitters may include calendar estimates as a comment, and report these estimates as cal $\mathrm{AD} / \mathrm{BC}$, citing the specific calibration curve used to obtain the estimate. Calibrated dates wil now be reported as "cal BP" or "cal AD/BC" according to the consensus of the Twelfth International Radiocarbon Conference, Trondheim, Norway, 1985.

Meaning of $\delta^{14} C$. In Volume 3, 1961, we endorsed the notation $\Delta$ (Lamont VIII, 1961) for geochemical measurements of ${ }^{14} \mathrm{C}$ activity, corrected for isotopic fractionation in samples and in the NBS oxalic-acid standard. The value of $\delta^{14} \mathrm{C}$ that entered the calculation of $\Delta$ was defined by reference to Lamont VI, 1959, and was corrected for age. This fact has been los sight of by editors as well as by authors, and recent papers have used $\delta^{14} \mathrm{C}$ as the ohserved deviation from the standard. At the New Zealand Radiocarbon Dating Conference it was recommended to use $\delta^{14} \mathrm{C}$ only for age-corrected samples. Without an age correction, the value should then be reported as percent of modern relative to 0.95 NBS oxalic acid (Proceedings 8th Conference on Radiocarbon Dating, Wellington, New Zealand, 1972). The Ninth International Radiocarbon Conference, Los Angeles and San Diego, 1976, recommended that the reference standard, 0.95 times NBS oxalic acid activity, be normalized to $\delta^{19} \mathrm{C}=-19 \%$

In several fields, however, age corrections are not possible. $\delta^{14} \mathrm{C}$ and $\Delta$, uncorrected for age, have been used extensively in oceanography, and are an integral part of models and theories. For the present, therefore, we continue the editorial policy of using $\Delta$ notations for samples not corrected for age. 


\section{CONTENTS}

Radiocarbon Dating of Deep-Sea Sediment's: A

Comparison of Accelerator Mass Spectrometer and Beta-Decay Methods

GA Jones, AJT Jull, TW Linick:and DJ Donahue

Problems Associated With the Use of Coal As a Source of

${ }^{14} \mathrm{C}=$ Free Backgrounid Material

David C Lowe.

Chronometric Dating-and Late Holocene Prehistory in the Hawaiian Islands: A Critical Review of Radiocarbon Dates from Moloka'i Island

Marshall Weisler

Accuracy and Precision in Dating Microgram Carbon

Samples

JS Vogel, DE Nelson and JR Southon.

High-Resolution ${ }^{14} \mathrm{C}$ Dating of Organic Deposits Using Natural Atmospheric ${ }^{14} \mathrm{C}$ Variations

Bas Van Geel and Willem G Mook

Anömalous AMS Radiocaarbon Ages for Foraminifera from High-Deposition-Rațe Ocean: Sediments

WS Broecker, Susan Trumbore, Georges Bonani, Willy Wölfi and Millie Klas

Temporal ${ }^{10} \mathrm{Be}$ and ${ }^{14} \mathrm{C}$ Variations: A Tool for

Pạleomagnetic Research

GE Kocharov, AV Blinovi, AN Konstantinov

and VA Levchenko.

Correcting ${ }^{14} \mathrm{C}$ Histograms for the Non-Linearity of the

${ }^{14} \mathrm{C}$ Time Scale Ad Stolk, Koos Hogervorst and Henk Berendsen

DATE LISTS

NOTES AND COMMENTS

LABORATORIES,

ANNOUNCEMENTS 